\title{
Breast Cancer in Young Brazilian Women: Challenge for the Oncology Care
}

\author{
Angela Andréia Franca Gravena, ${ }^{1}$ Catia Milene Dell Agnolo, ${ }^{2}$ \\ Tiara Cristina Romeiro Lopes, ${ }^{2}$ Marcela de Oliveira Demitto, ${ }^{2}$ William Augusto de Mello, ${ }^{1}$ \\ Deise Helena Pelloso Borghesan, ${ }^{1}$ Sheila Cristina Rocha Brischiliari, ${ }^{1}$ \\ Maria Dalva de Barros Carvalho, ${ }^{1}$ and Sandra Marisa Pelloso ${ }^{1,2}$
}

${ }^{1}$ Postgraduate Health Sciences Program, Maringa State University, Colombo Avenue 5790, 87020-900 Maringa, PR, Brazil

${ }^{2}$ Department of Nursing, Postgraduate Nursing Program, Maringa State University, Nossa Senhora da Glória Street, 56-A Jardim, São Jorge, 87080-620 Maringa, PR, Brazil

Correspondence should be addressed to Catia Milene Dell Agnolo; catiaagnolo@gmail.com

Received 3 January 2014; Revised 14 April 2014; Accepted 6 May 2014; Published 27 May 2014

Academic Editor: H. Anton-Culver

Copyright (C) 2014 Angela Andréia Franca Gravena et al. This is an open access article distributed under the Creative Commons Attribution License, which permits unrestricted use, distribution, and reproduction in any medium, provided the original work is properly cited.

\begin{abstract}
Objective. To investigate and compare aspects of breast cancer in young women ( $<40$ years old) with older women $(>40$ years old). Methods. Retrospective, cross-sectional, analytical, and exploratory study based on data from 2009 to 2012 obtained from the Breast Cancer Information System (SISMAMA) and the Unified Health System Information Data (DATASUS). The studied population consisted of women $(n=31.195)$ with malignant breast cancer. The analysed variables were education level, race, nodule detection at the clinical examination or image studies, presence of palpable axillary lymph nodes, surgical approach, and tumor histological type and grade. Results. There was increasing detection of breast cancer cases in young women among the studied years. Young women had more palpable lymph nodes (OR 1.28, 95\% CI: 1.18-1.39), ductal carcinoma as the most frequent histologic type (OR 1.36, 95\% CI: 1.22 to 1.53), and grades II and III tumor (OR 16.01, 95\% CI: 13.30 to 19.28 ). The lesion detection by clinical examination was higher in women $<40$ years (OR 1.34, 95\% CI: 1.24 to 1.45). Conclusion. Although there are early detection measures related to breast cancer, they are not the usual practice of the young female public, suggesting the need for a review of existing public policies in the country.
\end{abstract}

\section{Introduction}

Breast cancer has high prevalence and is among the leading causes of death worldwide. In Brazil, data from the National Cancer Institute (INCA) project 57,120 new cases of breast cancer in 2014, accounting for $20.8 \%$ of new cancers in women [1]. Data from the International Agency for Research on Cancer show that 1.38 million new breast cancer cases are diagnosed each year, representing more than $23 \%$ of all cancers among women [2].

Over the past 20 years, Public Health Policies were created with the aim of preventing cancer of the cervix and early detection of breast cancer, diseases whose actions are considered priority for the Health [3]. The National Policy for Cancer Care has tightened controls of breast cancer and cervical cancer as fundamental in the state and municipal health plans $[4,5]$ consolidating the existing political component. The recent National Plan of Policies for Women (PNPM) of the federal government, launched in 2013, proposes the reduction of cancer mortality in the female population, as well as promoting increased access to quality mammography in the public health system, ensuring detection and treatment in adequate time. Expanding access to breast cancer treatments and psychosocial support to women was also proposed [1].

In Brazil, the Ministry of Health recommends a mammography at least every two years for women 50-69 years of age $[1,3]$ and the annual clinical breast exam for women 40-49 years of age. For women considered to be at high risk of breast cancer (with family history of breast cancer in 
first-degree relatives), clinical breast exam and a mammogram every year starting at the age of 35 are recommended [3].

Although breast cancer occurs most often in women over the age of 50, several reports have been published suggesting an increase in the incidence and mortality in young women in different world populations [6]. In young women breast cancer is the leading cause of death in both western and developing countries [7], representing $5 \%$ to $7 \%$ of cases in some series [8].

Studies suggest that early breast cancer differs from breast cancer in the usual age, regarding etiology, tumor behavior, and prognosis [9-12]. These features can be partly explained by the fact that women under the age of 35 usually have more advanced breast cancer at diagnosis, a higher prevalence of axillary lymph node involvement, less differentiated tumors with a higher proliferation rate and a higher rate of recurrence of cancer [13].

The public service prioritizes screening for women over the age of 50, and breast cancer in young women is still poorly understood in Brazilian women. To our knowledge this study is the first attempt to analyze aspects related to breast cancer in young women. Thus the present study aimed to investigate and compare aspects of breast cancer in young women $(<40$ years) with older women cancer.

To our knowledge this study was the first analysis of some clinical and biological aspects of breast cancer in young women ( $<40$ years) in Brazil. Thus, the present study aimed to investigate and compare some demographic, clinical, and biological aspects of young patients with breast cancer compared with older women.

\section{Methods}

This is a retrospective, cross-sectional, analytical, and exploratory study, based on available epidemiological data of women with malignant breast cancer registered in the database of the Information System of Breast Cancer (SISMAMA) and the Unified Health System Data (DATASUS) of the Brazilian Ministry of Health $[14,15]$. The SISMAMA is an important tool for official information and provision of computerized data related to screening and diagnostic confirmation of breast cancer in Brazil (Ordinance 779 of 2008) [16].

The studied population consisted of Brazilian women with malignant breast cancer diagnosed between January 2009 and December 2012, separated into two groups according to the age at the diagnosis: young women (less than 40 years) and older women (more than 40 years).

The following variables were evaluated: education $(<8$ and $\geq 8$ years), race (black and nonblack), lesion detection (clinical breast examination or image study), palpable lymph nodes (presence or absence), histological type (ductal carcinoma or others) and degree (grades I or II and III) of the lesions, and surgical approach (simple or radical mastectomy).

Statistical tests were performed to evaluate demographic, clinical, and pathological characteristics in the two studied groups. The data analyses were performed using the TabWin

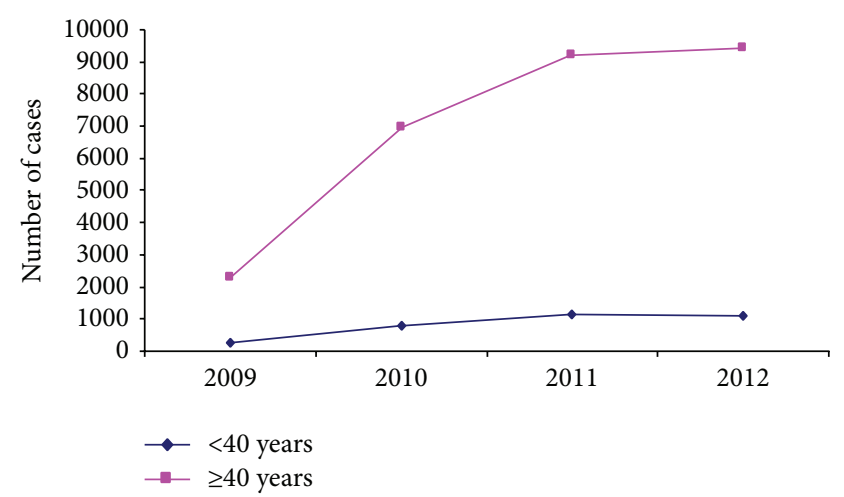

FIGURE 1: Number of cases of breast cancer in Brazilian women from January 2009 to December 2012.

(DATASUS) and Excel (Microsoft) software. For bivariate analysis statistical program Epi Info version 3.5.1 was used.

As the data was obtained from public domain databases, it was not necessary to refer the project to the Research Ethics Committee; however, the researchers followed all ethical provisions of Resolution CNS 466/2012 published by the Brazilian National Council of Health.

\section{Results}

A total of 31.195 cases of breast cancer were identified in Brazil between 2009 and 2012. Of this total, 3.039 (10.6\%) occurred in women younger than 40 . The number of cases of breast cancer increased between the years 2009 and 2012 for both groups of women (Figure 1).

It was observed that women younger than 40 years with less than 8 years of educational background were less likely to develop breast cancer than women with more than 8 years of education (OR 0.62, $P<0.001$ ) (Table 1 ).

The lesion detection by the clinical breast examination as well as the presence of palpable axillary lymph nodes was more common in women $<40$ (OR 1.34, $P<0.001$ and OR 1.28, $P<0.001$ ) (Table 1).

The most frequent histological type was ductal carcinoma compared to other histological types (10.9\% versus $8.2 \%$ ). According to the histological grade, younger women had 16.01 times more likely to develop grades II and III tumors than the older women $(P<0.001)$ (Table 1$)$.

\section{Discussion}

The definition of young women with breast cancer is still controversial in the literature, with different authors defining different ages as young, varying from 30 to 45 years $[9,17-$ 19]. In this study those less than 40 were considered as young women.

To our knowledge this is the first study of the clinical and biological aspects of breast cancer in Brazilian young women.

The total number of breast cancer cases found in this study was 31.195. An increase in the number of cases was identified between the years 2009 and 2012, similar to a research conducted in the United States that found an 
TABLE 1: Characteristics of breast cancer in Brazilian women from January 2009 to December 2012.

\begin{tabular}{|c|c|c|c|c|}
\hline \multirow{3}{*}{ Variables } & \multicolumn{2}{|c|}{ Age group } & \multirow{3}{*}{ OR (IC 95\%) } & \multirow{3}{*}{$P$ value } \\
\hline & $<40$ & $\geq 40$ & & \\
\hline & $N(\%)$ & $N(\%)$ & & \\
\hline Number of cases & $3309(10.6)$ & $27886(89.4)$ & & \\
\hline \multicolumn{5}{|l|}{ Education level } \\
\hline$<8$ years & $353(8.1)$ & 4049 (91.9) & $0.62(0.54-0.70)$ & \multirow{2}{*}{$<0.001$} \\
\hline$\geq 8$ years & $843(12.4)$ & $5961(87.6)$ & 1.0 & \\
\hline \multicolumn{5}{|l|}{ Lesion detection } \\
\hline Clinical breast exam & $2210(11.5)$ & $16939(88.5)$ & $1.34(1.24-1.45)$ & \multirow{2}{*}{$<0.001$} \\
\hline Image study & $973(8.8)$ & $9993(91.2)$ & 1.0 & \\
\hline \multicolumn{5}{|c|}{ Palpable axillary lymph node } \\
\hline Presence & $1124(11.9)$ & $8316(88.1)$ & $1.28(1.18-1.39)$ & \multirow{2}{*}{$<0.001$} \\
\hline Absence & $1635(9.5)$ & $15494(90.5)$ & 1.0 & \\
\hline \multicolumn{5}{|l|}{ Histological type } \\
\hline Ductal carcinoma & $2145(10.9)$ & $17468(89.1)$ & $1.36(1.22-1.53)$ & \multirow{2}{*}{$<0.001$} \\
\hline Others & $397(8.2)$ & $4413(91.8)$ & 1.0 & \\
\hline \multicolumn{5}{|l|}{ Histological degree } \\
\hline Grade I & $150(7.2)$ & $1932(92.8)$ & 1.0 & \multirow{2}{*}{$<0.001$} \\
\hline Grade II or III & $1621(11.1)$ & $13014(88.9)$ & $16.01(13.30-19.28)$ & \\
\hline \multicolumn{5}{|l|}{ Surgical approach } \\
\hline Simple mastectomy & $121(13.6)$ & $769(86.4)$ & 1.0 & \multirow{2}{*}{0.1305} \\
\hline Radical mastectomy & $354(11.6)$ & $2686(88.4)$ & $0.84(0.67-1.05)$ & \\
\hline
\end{tabular}

increased incidence of breast cancer with metastases in young women (aged 25-35) at the diagnosis (1.53 per 100.000 in 1976 to 2.90 per 100.000 in 2009 ), without a corresponding increase in older women [20].

The same increasing incidence of breast cancer among young women across the years was registered in Shanghai/China [21], France [22], and Spain [3].

Over the past decade the incidence of breast cancer is increasing among young women, worrying about public health factor. This increase in rates of breast cancer will have important implications for the costs of health services. Hospitalizations in the public health system for breast cancer and cervical cancer are those that require more spending on admissions and are related to loss of user productivity as well. In the period 2008-2011 the costs of hospitalization were 136 million [23].

The treatment of breast cancer also involves public spending. Mastectomy represented the largest spending of about 12 million dollars in the years 2008-2011. Chemotherapy was responsible for 564 million, totaling $\mathrm{R} \$ 712$ million spent in treatment, equivalent to $11.87 \%$ of total spending for all types of cancer. The expenses with prevention, promotion, and early detection totaled 176 million [23].

For individuals with cancer the government provides sickness benefits and sometimes disability retirement, expensive for public service [24].

The diagnosis and treatment of cancer have social, economic, physical, emotional/psychological, and sexual repercussions for individuals who receive this diagnosis and their families [25].
Study conducted in 2013 women with mastectomies reported that younger patients had to stop working due to cancer treatment, which gave them higher financial difficulties and poor quality of life related to vitality, social, and emotional aspects [26].

The increased incidence of breast cancer in young women should not be attributed to an improvement in the diagnostic methods, as young women are not included in public policies of screening.

Thus, the reduction in delayed diagnosis of breast cancer in our country implies the revision of the current official recommendations for the start of mammographic screening and adherence to this policy of public health.

The trend is that new cases of the disease diagnosed in advanced stages remain emerging from younger women attending public health services. A discussion should be made about the cost-effectiveness of implementation of mammography as a screening option for younger women in Brazil [27].

Mammography is less sensitive and specific for breast cancer screening in women under the age of 35 , due to the higher breast density [17]. According to Johnstone et al. [28], the mammography is normal in $90 \%$ of the breast cancers in young women. In the present study it was observed that younger women detect the cancer more frequently by the clinical examination (11.5\%) compared to imaging tests (8.8\%). Trufelli et al. (2008) [29] found that a palpable nodule is the main complaint of the consultation (75.4\%).

The clinical breast examination is recommended in Brazil only for women aged 40-49 [3]. Based on the recommendations established by the technical guidelines of the Ministry 
of Health, the inclusion of other diagnostic methods for breast cancer in young Brazilian women, such as the clinical examination of breast before the age of 40 , or even the use of ultrasound examination of breasts, and public policies that encourage the achievement of self-examination for young women [3], is suggested. These techniques would help in early diagnosis of breast cancer in young women, by presenting different clinical aspects of breast cancer in usual age $[17,18$, $30,31]$.

Regarding clinical characteristics, the presence of palpable axillary lymph nodes was higher in women younger than 40. Other authors have obtained similar results [18, 31, 32]. A survey of women with breast cancer under the age of 30 found that in $90 \%$ of cases the first signal was a clinically palpable nodule, with an average size of $3.5 \mathrm{~cm}$ [32]. Higher rates of involvement of axillary lymph nodes are described in patients under the age of 40 compared with older patients [33]. A Nepal study with 944 breast cancer patients admitted to a University Hospital between November 1997 and October 2012 identified that axillary lymph nodes were positive in $73 \%$ of younger patients ( $<40$ years) and $59 \%$ of older patients $(P=0.002)$ [31]. These findings suggest that breast cancer in young women is more aggressive, with the involvement of axillary lymph nodes at diagnosis indicating the severity of the disease in this age group.

Similarly to other studies, the most frequent histological type of breast cancer in young women was ductal carcinoma [31, 34, 35]. Bouzid et al. (2013) [17], in an analytical retrospective survey conducted in Tunisia with breast cancer women younger than 35 , identified that the infiltrating ductal carcinoma was present in $95 \%$ of cases.

Although the histological type most often found in young women has been infiltrating ductal carcinoma, it is known that the breast cancer manifests more aggressively at this age [36]. What explains the aggressiveness of breast cancer in young women is the histological grade of the lesion $[18,34$, $37,38]$. In the present study, younger women were 16.01 times more likely to develop grades II and III tumors than older women. Bouzid et al. (2013) [17] found that grades II and III tumors were present in $41.1 \%$ and $37.1 \%$ of cases, respectively. Dimitrakakis et al. (2013) [30] when comparing groups of women with cancer at age less than 25 with breast cancer women aged more than 25 noted that the first group exhibited a higher histological grade.

Breast cancer prognosis is poorer in young women than in older women $[17,30,39,40]$. It is usually characterized by recurrence rate between 20 and 30\%, higher incidence of advanced histological grade, advanced stage at diagnosis, more frequent BRCA1 mutations [41], and higher rate of cell proliferation [39, 42].

Freedman and Partridge (2013) [4] asserted that the reasons for the biological differences for breast cancer at different ages are poorly understood. However mutations in BRCA1 may explain some of the types of high-grade triple negative cancer observed in young women.

There is no scientific evidence that lower educational background is a protective factor for breast cancer. However, one can assume that, in Brazil, by socioeconomic and cultural reasons, this population consumes less animal fat, eats more vegetables, and has longer breastfeeding.

This study has some limitation. It was retrospective and missing data from Public Health Agencies is a problem, making the understanding of the real scenario of the breast cancer in Brazilian young women difficult.

Early detection of breast cancer appears to be of utmost importance to support public policies that address women's health, the implementation of screening programs, and to provide data for clinical research. The trend is that new cases of the disease, diagnosed in advanced stages, continue emerging from younger women attending public health services. Further studies of the breast cancer in young women are needed.

\section{Conclusion}

There was an increase in cases of breast cancer in young women among the studied years. Young women with breast cancer had more palpable axillary lymph nodes, ductal carcinoma as the most frequent histological type, and more advanced tumor grade when compared with older women. An important finding of this study was the identification that the clinical examination was the main tool of breast cancer diagnosis in younger women. Clinical protocols and public policies that encourage this form of detection for young women are advisable in Brazil.

In this sense, we suggest a review of existing public policies in the country, besides conducting new studies to assess the real impact of the use of mammography as a screening in women in general, even those who have low risk of breast cancer, considering the other risk factors, as well as deploy other methods of screening in younger women, aiming at a reduction in the prevalence of breast cancer in Brazil.

\section{Conflict of Interests}

The authors declare that there is no conflict of interests regarding the publication of this paper.

\section{References}

[1] Brasil, Ministério da Saúde, Estimativa de 2014, Incidência de câncer no Brasil, Instituto Nacional de Câncer, Ministério da Saúde, 2013.

[2] J. Ferlay, H. R. Shin, F. Bray, D. Forman, C. Mathers, and D. M. Parkin, "Cancer Incidence and Mortality Worldwide: IARC Cancer Base," GLOBOCAN 2008, no. 10, International Agency for Research on Cancer, Lyon, France, 2010.

[3] M. Pollán, R. Pastor-Barriuso, E. Ardanaz et al., "Recent changes in breast cancer incidence in Spain, 1980-2004," The Journal of the National Cancer Institute, vol. 101, no. 22, pp. 1584-1591, 2009.

[4] R. A. Freedman and A. H. Partridge, "Management of breast cancer in very young women," The Breast, vol. 22, pp. 176-179, 2013.

[5] Brasil. Ministério da Saúde. Portaria 2439, de 08 de dezembro de 2005, "Institui a Política Nacional de Atenção Oncológica: Promoção, Prevenção, Diagnóstico, Tratamento, Reabilitação e Cuidados Paliativos, a ser implantada em todas as unidades 
federadas, respeitadas as competências das três esferas de gestão," Diário Oficial [da] Republica Federativa do Brasil. Brasília, DF, 2005 Dez 09; Seção 1, fls.80-81.

[6] S. Santos, Câncer de mama em mulheres jovens: incidência, mortalidade e associação com os polimorfismos dos genes NQO1, CYP17 e CYP19 [Tese], Escola Nacional de Saúde Pública Sérgio Arouca, Rio de Janeiro, Brazil, 2013.

[7] American Cancer Society, Breast Cancer Facts \& Figures 2011 e 2012, American Cancer Society, Atlanta, Ga, USA, 2012.

[8] D. F. Hayes, "Follow-up of patients with early breast cancer," New England Journal of Medicine, vol. 356, no. 24, pp. 25052513, 2007.

[9] M. A. Bollet, B. Sigal-Zafrani, V. Mazeau et al., "Age remains the first prognostic factor for loco-regional breast cancer recurrence in young ( $<40$ years) women treated with breast conserving surgery first," Radiotherapy and Oncology, vol. 82, no. 3, pp. 272-280, 2007.

[10] C. K. Anders, R. Johnson, J. Litton, M. Phillips, and A. Bleyer, "Breast cancer before age 40 years," Seminars in Oncology, vol. 36, no. 3, pp. 237-249, 2009.

[11] H. Fredholm, S. Eaker, J. Frisell, L. Holmberg, I. Fredriksson, and H. Lindman, "Breast cancer in young women: poor survival despite intensive treatment," PLoS ONE, vol. 4, no. 11, Article ID e7695, 2009.

[12] J. Tichy, E. Lim, and C. Anders, "Breast cancer in adolescents and young adults: a review with a focus on biology," Journal of the National Compreensive Cancer Network, vol. 11, pp. 10601069, 2013.

[13] G. M. Swanson, S. Z. Haslam, and F. Azzouz, "Breast cancer among young African-American women: a summary of data and literature and of issues discussed during the "Summit Meeting on Breast Cancer Among African American Women," Washington, DC, September 8-10, 2000," Cancer, vol. 97, no. 1, pp. 273-279, 2003.

[14] Brasil, DATASUS, Ministério da Saúde, Departamento de Informática do SUS, Informações de saúde, Estatísticas vitais, http://www2.datasus.gov.br/DATASUS/index.php?area=0205.

[15] Brasil, Ministério da Saúde, DATASUS, Informações de saúde, Epidemiologia e Morbidade, http://www2.datasus.gov.br/ DATASUS/index.php?area=0203.

[16] Brasil, Ministério da Saúde, Portaria 779/31 de dezembro de 2008, http://dtr2001.saude.gov.br/sas/PORTARIAS/Port2008/ PT-779.htm.

[17] N. Bouzid, R. Lahmar, S. Tebra, and N. Bouaouina, "Cancer du sein chez la femme jeune de moins de 35 ans en Tunisie: étude rétrospective à propos de 124 cas," Gynécologie Obstétrique \& Fertilité, vol. 41, pp. 356-360, 2013.

[18] H. Boufettal, M. Noun, and N. Samouh, "Breast cancer in young patient in Morrocco," Cancer Radiotherapy, vol. 14, no. 8, pp. 698-703, 2010.

[19] G. Coulombe, S. Tyldesley, C. Speers et al., "Is mastectomy superior to breast-conserving treatment for young women?" International Journal of Radiation Oncology Biology Physics, vol. 67, no. 5, pp. 1282-1290, 2007.

[20] R. Johnson, F. Chien, and A. Bleyer, "Incidence of breast cancer with distant involvement among women in the United States, 1976 to 2009," The Journal of the American Medical Association, vol. 309, no. 8, pp. 800-805, 2013.

[21] Q. Wu, E. Vogtmann, W. Zhang et al., "Cancer incidence among adolescents and young adults in urban Shanghai, 1973-2005," PLoS ONE, vol. 7, no. 8, Article ID 42607, 2012.
[22] A. M. Fontenoy, C. Leux, S. Delacour-Billon et al., "Recent trends in breast cancer incidence rates in the Loire-Atlantique, France: a decline since 2003," Cancer Epidemiology, vol. 34, no. 3, pp. 238-243, 2010.

[23] Brasil. Ministério da Saúde. Secretária de Vigilância em Saúde. Departamento de Análise da Situação de Saúde. Departamento de Informática do Sistema Único em Saúde (DataSus). Sistema de Informações Hospitalares do SUS, (SIH/SUS), 2012.

[24] Instituto Nacional de Câncer, "Direitos sociais da pessoa com câncer/Instituto Nacional de CÂNCER Jose Alencar Gomes da Silva. Coordenação Geral de ações estratégicas. Divisão de comunicação social," INCA, Rio de Janeiro, Brazil, 3rd edition, 2012.

[25] J. S. Gomes, H. K. Lichtenfels, A. C. B. Kolankiewicz et al., "Qualidade de vida na oncologia: uma revisão bibliográfica," Revista Contexto e Saúde, vol. 10, no. 20, pp. 463-472, 2011.

[26] V. L. A. Furlan, M. Sabrino-Neto, L. E. F. Abla et al., "Qualidade de vida e autoestima de pacientes mastectomizadas submetidas ou não a reconstrução de mama," Revista Brasileira de Cirurgia Plástica, vol. 28, no. 2, pp. 264-269, 2013.

[27] C. A. Martins, R. M. Guimarães, R. L. P. D. Silva et al., "Evolução da mortalidade por câncer de mama em mulheres jovens: desafios para uma política de atenção oncológica," Revista Brasileira de Cancerologia, vol. 59, no. 3, pp. 341-349, 2013.

[28] P. Johnstone, E. Moore, R. Carillo, and C. Goepfert, "Yield of mammography in selected patients age $<30$ years," Cancer, vol. 91, pp. 1075-1078, 2001.

[29] D. Trufelli, V. Miranda, M. Santos et al., "Análise do Atraso no Diagnóstico e Tratamento do Câncer de mama em Hospital Público," Revista da Associação Médica Brasileira, vol. 54, no. 1, pp. 72-76, 2008.

[30] C. Dimitrakakis, A. Tsigginou, F. Z. S. Marinopoulos et al., "Breast cancer in women aged 25 years and younger," Obstetrics and Gynecology, vol. 121, no. 6, pp. 1235-1240, 2013.

[31] B. Thapa, Y. Singh, P. Sayami, U. Shrestha, R. Sapkota, and G. Sayami, "Breast cancer in young women from a low risk population in Nepal," Asian Pacific Journal of Cancer Prevention, vol. 14, no. 9, pp. 5095-5099, 2013.

[32] E. B. Vargas, A. R. Bau, and V. R. A. Vargas, "Analise dos diagnósticos das doencas da mama de mulheres jovnes que apresentaram queixas mamarias," Revista Brasileira de Mastologia, vol. 19, no. 4, pp. 141-145, 2009.

[33] C. S. Foo, D. Su, C. K. Chong et al., "Breast cancer in young Asian women: study on survival," ANZ Journal of Surgery, vol. 75, no. 7, pp. 566-572, 2005.

[34] A. Khanfir, M. Frikha, F. Kallel et al., "Le cancer du sein de la femme jeune dans le sud tunisien," Cancer/Radiothérapie, vol. 10, pp. 565-571, 2006.

[35] H. Bakkali, C. Marchal, A. Lesur-Schwander, and J. L. Verhaeghe, "Le cancer du sein chez la femme de 30 ans et moins," Cancer/Radiothérapie, vol. 7, pp. 153-159, 2003.

[36] C. S. Fassarella, A. A. B. Bueno, B. C. S. Ramos, and F. G. S. Toste, "O impacto da notícia de neoplasia de mama em mulheres jovens: revisão de literatura," Revista Rede de Cuidados em Saúde, vol. 7, no. 1, pp. 1-10, 2013.

[37] A. Sidoni, A. Cavaliere, G. Bellezza, M. Scheibel, and E. Bucciarelli, "Breast cancer in young women: clinicopathological features and biological specificity," Breast, vol. 12, no. 4, pp. 247250, 2003.

[38] S. Jmor, H. Al Sayeh, S. D. Heyes, S. Paynes, I. Miller, and A. AhSeea, "Breast cancer in women aged 35 and under: prognosis 
and survival," Journal Royal College of Surgeons Edinburgh, vol. 47, no. 6, pp. 693-699, 2002.

[39] A. Kwong, P. Cheung, S. Chan, and S. Lau, "Breast cancer in Chinese women younger than age 40: are they different from their older counterparts?" World Journal of Surgery, vol. 32, no. 12, pp. 2554-2561, 2008.

[40] G. Cancello, P. Maisonneuve, N. Rotmensz et al., "Prognosis and adjuvant treatment effects in selected breast cancer subtypes of very young women ( $<35$ years) with operable breast cancer," Annals of Oncology, vol. 21, no. 10, pp. 1974-1981, 2010.

[41] M. A. Maggard, J. B. O’Connell, K. E. Lane, J. H. Liu, D. A. Etzioni, and C. Y. Ko, "Do young breast cancer patients have worse outcomes?" Journal of Surgical Research, vol. 113, no. 1, pp. 109-113, 2003.

[42] S. Aebi and M. Castiglione, "The enigma of young age," Annals of Oncology, vol. 17, no. 10, pp. 1475-1477, 2006. 


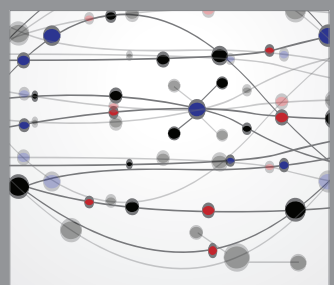

The Scientific World Journal
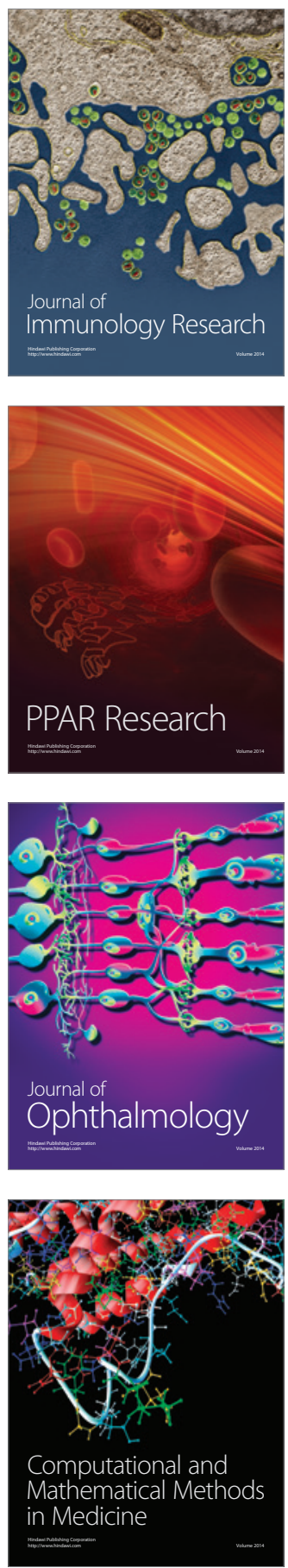

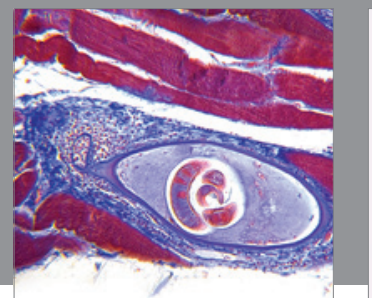

Gastroenterology

Research and Practice
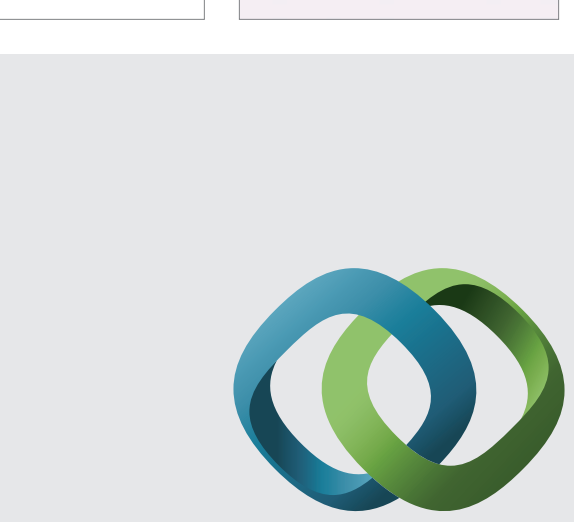

\section{Hindawi}

Submit your manuscripts at

http://www.hindawi.com
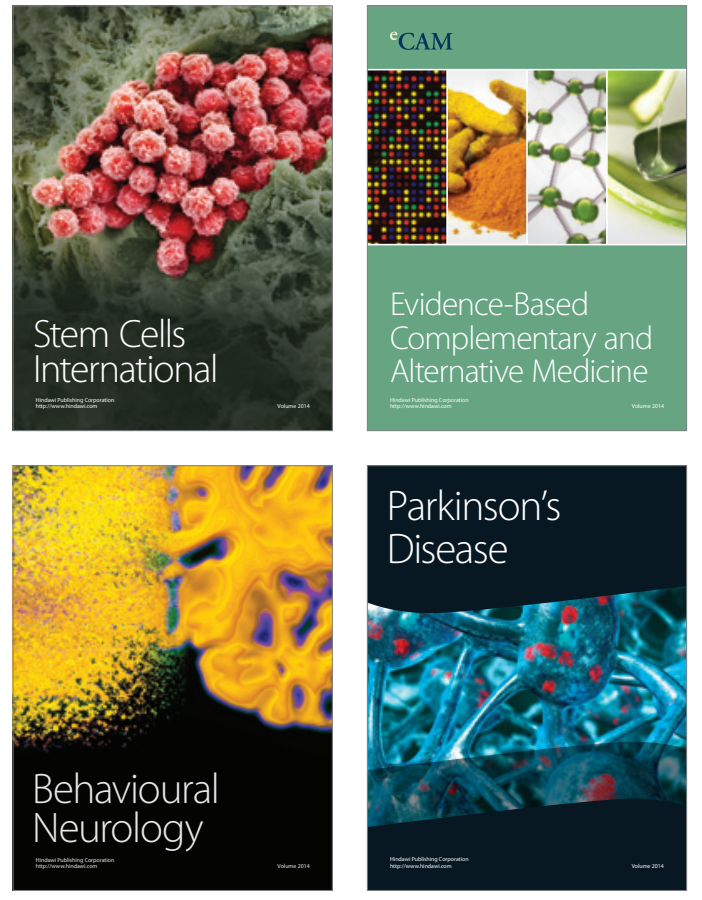
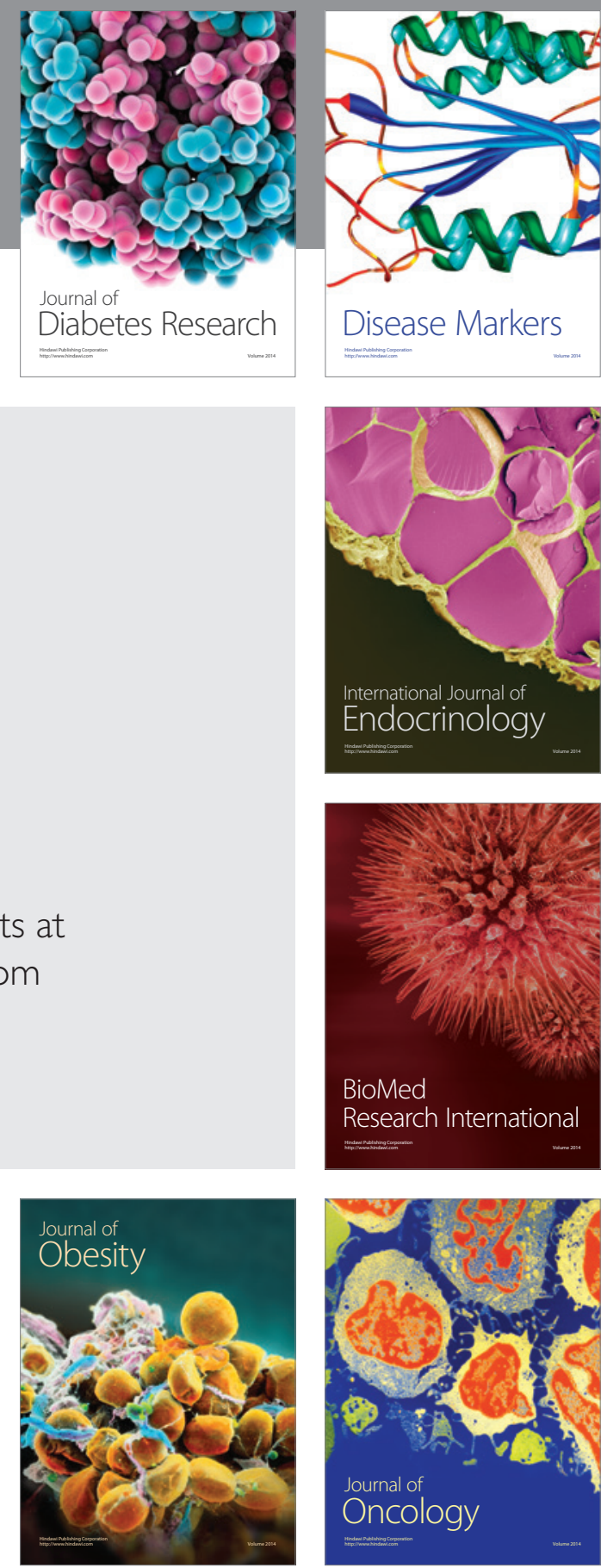

Disease Markers
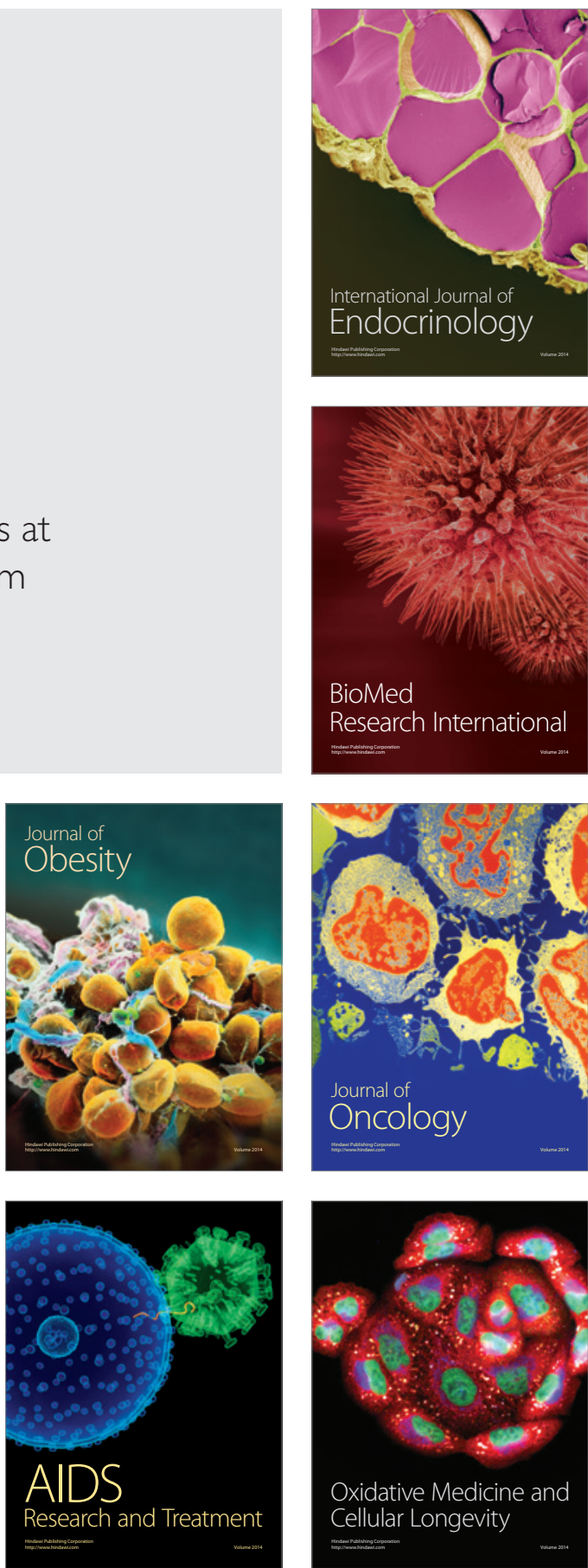